\title{
Educating with Paying Attention to Individual Differences: Case Study of Slow Learner Students in Inclusion School
}

\author{
$1^{\text {st }}$ Sutipyo Ru'iya \\ Department of Islamic Education \\ Universitas Ahmad Dahlan \\ Jalan Ring Road Selatan, Tamanan \\ Bantul, Yogyakarta, Indonesia \\ sutipyo@pai.uad.ac.id
}

\author{
$2^{\text {nd }}$ Hanif Cahyo Adi Kistoro \\ Department of Islamic Education \\ Universitas Ahmad Dahlan \\ Jalan Ring Road Selatan, Tamanan \\ Bantul, Yogyakarta, Indonesia
}

\author{
$3^{\text {rd }}$ Sutarman \\ Department of Islamic Education \\ Universitas Ahmad Dahlan \\ Jalan Ring Road Selatan, Tamanan \\ Bantul, Yogyakarta, Indonesia
}

\begin{abstract}
Each student has a uniqueness that must be considered by the teacher in the learning process, unusually slow learner children with various peculiarities. This study aims to reveal the attention of Islamic Religious Education teachers to slow learner children. This study is qualitative research with a survey approach-data sources of Islamic religious education teachers in inclusive schools with their specificity of slow learner students. Through in-depth interviews, the data is extracted from the source. After the data is collected, then it is analyzed through a grounded theory strategy. The analysis uses several stages, namely arranging them into categories, then deciding in a theoretical model, and finally describing them in the relations between classifications. The result of this study is Islamic Religious Education teachers always pay more attention to slow learner children. It is done by simplifying the material and language according to their circumstances and also doing material repetition. Through various kinds of attention to individual differences as such, slow learner children can participate in learning and achieve competencies similar to healthy children.
\end{abstract}

Keywords-Educating, Paying Attention, Case Study, Inclusion School

\section{INTRODUCTION}

Education is a right for every child, both normal and non-native children / children with special needs. Regulation Number 20 of 2003 states: "Every citizen has the same right to obtain education ..." The law mandates that the education of children with special needs be carried out separately in Extraordinary Schools (SLB). The separation of children with special needs in SLB impacts exclusiveism in education.

Exclusivity in education results in the disabled group becoming a community alienated from social dynamics in society. People are not familiar with the lives of disabled groups. While disability groups themselves feel that their existence is not an integral part of the lives of the surrounding community.[1] As a result, children with special needs (ABK) are always looked down on and unimportant. This reality must be changed immediately so that children with special needs are not increasingly introverted.[2]

Meanwhile, in the international convention Education for All (EFA), The Dakar Framework for Action[3], and Conventional on the Right of the Person with Disabilities and Optional Protocol in 2007[2] mandated that Education should be enjoyed by both normal people and people with special needs. To respond to all the results of the international conventions, the Indonesian Government issued the National Education Minister Regulation No. 70 of 2009 on the implementation of inclusive Education. To strengthen this program, the Indonesian Government lowered Government Regulation Number 19 of 2015. In article 41 paragraph (1), Regulation No. 19 states that: "Every educational unit implementing inclusive education must have educators who have competence organize learning for learners with special needs."

In response to the above regulation, all teachers who teach in inclusive schools must develop their competencies to deal with the diversity of their students. Meanwhile, not all teachers have competencies in dealing with children with special needs. This is what drives researchers to find out how Islamic Religious Education teachers at Pandansimping Public Elementary School, Prambanan District, Klaten Regency teach in inclusive classes. Meanwhile in SDN Pandansimping in each class there are children with special needs slow learner categories.[4]

\section{SLOW LEARNER CHILDREN AND ISLAMIC RELIGIOUS EDUCATION}

\section{A. Slow learner and characteristics}

In the APA dictionary, slow learner (SL) means a child with below-average intelligence.[5] Other terms of SL are student's slow learning or mental retardation, [6] mild cognitive impairment, and general learning disabilities.[7] Another definition of SL is a child who is unsuccessful in learning because of his minimum psychological and cognitive abilities. Slow learners are 
students who are slow learners, so it requires more time compared to other students who have normal intellectuals.[8] A slow learner is a child who has a slightly below normal intellectual potential but does not include mentally disabled children.[9], [10] While Chauhan said that SL is a child who is very retarded in basic subjects, so they need special assistance.

From the intelligence side, slow learner children usually have an IQ between 70-85.[11] Peatling says that slow learner children are further divided into two groups: backward (i.e., those who have an intelligence test score from 67 to 89) and sub-normal (that is, those who have an intelligence test score from 90 to 100).[12] From some of the definitions that have been submitted, it is clear that slow learner children are children who have lower cognitive abilities than normal children. They will take longer to understand certain subjects if they are treated the same as normal children. However, slow learner children are not included in the category of mentally disabled, therefore, so that slow learner can take lessons as normal children need help or unique treatments.

Slow learner children have distinctive characteristics that are different from normal children. One striking feature is that they have difficulty understanding subjects, especially those which are abstract. Slow learner children are usually unable to cope with work that is generally expected of their age group. Slow learner children also have communication problems and have emotions that are less stable and difficult to socialize. Therefore, children who have severe emotional and social difficulties must be placed in a particular class because they require specialized therapy.[13] For those who show no real symptoms of social and emotional inability and are usually placed in regular classes.[5] Chauhan divides the handling of slow learner children into two, namely: a) Children who need separate handlers. b) Children who can be won in integrated education. The nature and severity of learning retardation and academic retardation in these children are not too severe, so that education can be carried out with students who are public and integrated into the existing schools (inclusion).[10]

\section{B. Islamic Religious Education}

Islamic Religious Education is a subject intended to produce students who are devoted to God Almighty. Islamic Religious Education is urgently needed by Muslims, in order to help them truly teach Islam as a perfect religion (kamil), perfection of Islamic teachings that are studied integrally (kafah) is expected to improve the quality of Muslims in various fields of life. So that Islamic teachings can be studied effectively and efficiently, it is necessary to develop Islamic education curriculum in accordance with the development and development of the times.

Islamic Education Materials include: a) Al-Qurān Hadith, is the first and foremost source of law in Islam, therefore it is obligatory for Muslims to understand it. b) Aqēdah and Akhlāq, emphasizes the ability to understand the faith and belief of Islam which is applied in life in the form of the values of al-Asma 'al-husna. Aqēdah that is true and straight will have an impact on good and noble character. Noble akhlāq apply and decorate themselves laudable morals (mahmudah) and stay away from and avoid oneself from blamed morals (mazmumah) in everyday life.[14] c) Jurisprudence, emphasizes the correct understanding of the legal provisions in Islam which are implemented in everyday life. Good jurisprudence is according to the guidance of the Prophet Muhammad. d) Islamic Cultural History (SKI), emphasizing the ability to take ibrah/wisdom (lessons) from Islamic history, emulate outstanding figures, and relate them to the phenomena of life today and in the future.

Zakiyah Darajat [15] said that Islamic Education touches on human multi dimensions which include: a) Physical dimensions that aim to strengthen the human body so that it can carry out the task of the Caliphate. b) Dimension of reason that aims at reason and human reason so that he can think of verses of kauniyah and verses of qauliyah c) Dimensions of faith that aim to strengthen confidence and trust in Allah SWT as God. d) Moral dimension which aims to develop human behavior in accordance with the teachings of the right religion. e) Dimensions of psychology, which aims to link the physical frequency, and reason with the frequency of Allah. Ghorbani formulated briefly that the aim of Islamic Religious Education was taught so that children become good-minded people in accordance with the values of Islamic teachings that are kaffah insan kamil.[16]

C. Islamic Religious Education for slow learners

Peatling which discusses religious education in general for slow learner children. Peatling recommends that religious education for slow learners pay attention to the developmental stage guidelines as Jean Piaget's theory of cognitive development stages.[12] Paying attention to Jean Piaget's developmental stage is a wise step because learning is closely related to students' cognitive abilities. Delivering subject matter beyond the cognitive abilities of children will be in vain because the material becomes abstract. The child will not understand the material presented while Mohammad and Mahmoud said that in dealing with slow learner children, educational institutions must critically and seriously take them. Specific methods, curricula, and snacks need to be formulated for slow learners to learn optimally.[17]

Islamic Education Learning delivered by Widada[18] for mentally disabled children, should adhere to several principles, including a) Simplifying the material (downgrade). b) Avoid abstract, theoretical, and verbal submission of PAI material. c) Submit PAI material in a contextual, practical, accessible, visual, gradual, continuous and repetitive manner, so that students can accept and understand. d) Optimizing the affective and psychomotor potential rather than cognitive. e) The individual approach is more important than classical. f) Use the media and methods that suit the needs of the participants.

\section{METHODS}

This type of research is qualitative research with a survey approach. This study examined the behavior of a teacher of Islamic Religious Education who teach by 
observing the different students in a class taught. This Islamic Religious Education teacher also doubles as a Guidance and Counseling teacher in a Pandansimping Public Elementary School in the Prambanan district of Klaten Regency.

This research is qualitative research with a survey approach. This study examines the behavior of an Islamic Religious Education teacher who teaches by paying attention to differences in students in each class. The number of slow learners in each class ranges from 1-2 people, and the number of students in each class ranges from 10-24 people. This research focuses on teaching Islamic Religious Education in the third grade because the highest number of students is 24 people and two slow learner students with mild and moderate SL. Class conditions are quite diverse, of course, require special attention to all teachers who teach in this class.

Data were collected through in-depth interviews with Islamic Religious Education teachers and some slow learner students. To strengthen the data, continued with observation when the Islamic Religious Education teacher taught. After the data is collected, then it is analyzed through a grounded theory strategy, according to Creswell[19], with the following stages: a) Perform data selection. Digging data through in-depth interviews with Islamic Religious Education Teachers and observation during learning. b) Data analysis. The data analysis stages are: 1) open coding; 2) axial coding; 3) selective coding. c) Preparation of theory. The process of preparing arguments through the analysis of relationships between all categories. The opinions are then written in the form of narratives that describe the interconnectedness of all classes.

\section{RESULT AND DISCUSSION}

\section{A. Teacher's perception of Islamic Religious Education to children of slow learners}

Most teachers at this school treat the same thing between SL children and normal children. But it is different from Islamic Religious Education teachers, where he pays special attention to children who have SL. Islamic Education Teachers assume that SL children are special children who are entrusted by God to all teachers to educate. By the Prophet's hadith that: "Every child is born in a state of nature...."[20] This is evident from the attitude and behavior of GPAI when implementing the learning process, namely paying particular attention and more to SL children. The GPAI said: "I had the privilege of God's surrogate parenting slow learner, so that trust and confidence should be our watch."

At some point, the SL child loses control[13] because of being played by his classmates, so the GPAI treats him patiently. The child is persuaded and appeased so that his emotions can be controlled again. This attitude and behavior make these two SL children in third grade feel comfortable learning with GPAI.
B. Islamic Religious Education Learning for slow learner children

1. We are paying attention to the characteristics of slow learner children. A wise teacher must pay attention to each of his students' characteristics [21], so does this GPAI. Slow learner children who are weak in managing emotions, resulting in frequent problems with friends. Responding to this, Islamic Religious Education Teachers always try to pay attention to SL students. The way this teacher is paying attention is to approach, communicate a lot with SL children, and often give praise. This method can be considered a treatment to manage SL children's emotions and was quite successful.[22]

2. Simplifying subject matter. Islamic Religious Education Materials in slow learners are mostly the same as normal children. However, when delivered to SL students, GPAI often makes simplifications. Existing material is usually made a material summary, so they are not burdened with narratives that are so long.[18] This principle is fundamental to all teachers who teach slow learners because their main obstacle is cognitive ability.[23]

3. Simplify language. Simplifications language and foreign vocabulary will make it difficult for children to understand the lessons, especially for SL children. Simplification of language is also important because SL children do not have language growth as fast as normal children. GPAI often conveys subject matter using simplifying language(Javanese). By simplifying language, SL children understand more quickly what is meant from the subject matter. According to psychologists, simplifying language is very supportive of children in learning everyday language.[24], [25]

4. Repeating material. Repetition or repetition is one method that is widely used in learning SL children. Weak cognitive abilities of SL as mentally disabled children need repetition to strengthen their memory. The repetition of remembrance will be more persuasive, so memories that are still in the short term memory will be pushed into the long term memory. Muzdalifah said that in the study of neuroscience, repetition is beneficial in strengthening minds. [26]

5. Visualize the material. The visualized material will be easier to understand because it looks concrete for SL children as the development theory J. Piaget.[10] This is a challenge for GPAI because many Islamic religious education materials cannot be visualized, primarily related to aqidah. For example, when teaching about the existence of God and that God is different from beings. But for material that can be visualized, GPAI always tries to do visualization to help SL children to understand the subject matter quickly. For example, when learning about slat, you must tap the Qibla. So GPAI tried to make a miniature Kāaba.

6. Prioritize practice. Slow learners often have additional specificities such as hyperactivity, autism, 
or others.[10] They prefer to practice more than many with long narratives. The practice and variety of learning conducted by GPAI make SL children happy and diligent in learning.

7. Use a variety of media. GPAI's creativity in conducting learning is very much needed, especially in the use of media. For example, using miniature Kaaba. This method has also been carried out by Herlinda, who uses audio-visual media to improve SL children's reading abilities.[27] Meanwhile, Wulandari used stamp game media to develop numeracy skills in SL students.[28]

Various efforts made, as described above, resulted in the achievements and achievements of SL children in SDN Pandansimping that can match normal children. At the end of the semester, slow learner children can achieve minimum completeness criteria (KKM) in Islamic education subjects as planned in the Learning Program Plan (RPP)

\section{CONCLUSION}

From the above it can be concluded that the implementation of Islamic religious education learning for children in SDN Pandansimping slow learner very attentive to differences in students. Slow learner child should be given more attention than in normal children so that they can reach KKM subjects of Islamic religious education have been set. As for other tips that do Islamic religious education teachers is to simplify the material presented, to simplify the language, repeating the material, and often visualize the material through a variety of media, and more focused on practice.

\section{ACKNOWLEDGMENT}

Thanks to Universitas Ahmad Dahlan who has given support to researchers so that research funding can be completed on time. Thanks infinite to friends department of Islamic education that contribute ideas so that this paper can be in the publication.

\section{REFERENCES}

[1] S. Y. Bangun, "Pengembangan Pengetahuan Anak Difabel Melalui Pendidikan Jasmani Olahraga dan Outbound," PJKR, vol. 1 , no. 1, pp. 70-77, Okt 2016

[2] N. Praptiningrum, "Fenomena penyelenggaraan pendidikan inklusif bagi anak berkebutuhan khusus," Jurnal Pendidikan Khusus, vol. 7, no. 1, pp. 32-38, 2010.

[3] R. Fernandes, "Adaptasi Sekolah Terhadap Kebijakan Pendidikan Inklusif," soc, vol. 4, no. 2, pp. 119-125, Mar 2018.

[4] N. K. Dewi, "Manfaat program pendidikan inklusi untuk AUD," Jurnal Pendidikan Anak, vol. 6, no. 1, p. 12-19, 2017.

[5] G. R. VandenBos, APA Dictionary of Psychology. Washington DC: American Psychological Association, 2007.

[6] E. Gaad, Inclusive Education in the Middle East. New York: Routledge, 2011.

[7] E. Boeriswati, "Peers' Instructional Interactions in Inclusive Classrooms: Slow Learner Students and Typical Students," International Journal of Multidisciplinary and Current Research, vol. 2, no. 1, pp. 904-911, 2017.
[8] W. Amelia, "Karakteristik dan Jenis Kesulitan Belajar Anak Slow Learner," J. Sci. n. a, vol. 1, no. 2, pp. 53-58, Des 2016 a. v1i2. 21.

[9] F. R. Hadi, "Proses Pembelajaran Matematika Pada Anak Slow Learners (Lamban Belajar)," Premiere Educandum, vol. 6, no. 1, pp. 36-41, 2016.

[10] S. Chauhan, "Slow Learners: Their Psychology And Educational Programmes," ZENITH: International Journal of Multidisciplinary Research, vol. 1, no. 8, pp. 279-289, 2011.

[11] K. S. Cooter and R. B. Cooter, "Issues in Urban Literacy: One Size Doesn't Fit All: Slow Learners in the Reading Classroom," The Reading Teacher, vol. 57, no. 4, pp. 680-684, 2014.

[12] J. H. Peatling, "The slow learner and religious education: A research note," Learning for Living, vol. 14, no. 3, pp. 102-106, Jan 1975.

[13] M. Shokoohi-Yekta, N. Zamani, and A. Ahmadi, "Anger management training for mothers of mildly mentally retarded and slow learner children: effects on mother-child relationship," Procedia - Social and Behavioral Sciences, vol. 15, pp. 722726, 2011.

[14] S. Ru'iya, "Strengthening Morality And Character of Madrasah Tsanawiyah's Students in Kulon Progo by Developing Good Habits and Effective Communication With Parents," Advances in Social Science, Education and Humanities Research, vol. 317, pp. 172-176, 2019

[15] Z. Darajat, Pendidikan Islam Dalam Keluarga dan Sekolah. Jakarta: Ruhama, 1994.

[16] N. Ghorbani, P. J. Watson, M. Omidbeiki, and Z. J. Chen, "Muslim attachments to God and the 'perfect man' (Ensān-e Kāmel): Relationships with religious orientation and psychological adjustment in Iran," Psychology of Religion and Spirituality, vol. 8, no. 4, pp. 318-329, Nov 2016.

[17] T. Z. Mohammad and A. M. Mahmoud, "Clustering of Slow Learners Behavior for Discovery of Optimal Patterns of Learning," ijacsa, vol. 5, no. 11, 2014.

[18] Widada, "Implementasi Pendidikan Agama Islam Adaptif Bagi Siswa SMALB Tunagrahita Ringan Kelas X di SLB Negeri Pembina Yogyakarta," Al-Misbah, vol. 2, no. 1, pp. 84-105, 2014.

[19] J. W. Creswell, Research Design, Pendekatan Kualitatif, Kuantitatif, dan Mixed. Yogyakarta: Pustaka Pelajar, 2014.

[20] A. N. Ulwan, Tarbiyatul Aulad fi Islam (Pendidikan Anak dalam Islam). Jakarta: Putaka Amani, 2020.

[21] M. M. Gerber, "Cognitive-Behavioral Training in the Curriculum: Time, Slow Learners, and Basic Skills," Focus on Exceptional Children, vol. 18, no. 6, hlm. 12, 1986.

[22] N. I. Malik, G. Rehman, dan R. Hanif, "Effect of Academic Interventions on the Developmental Skills of Slow Learners," hlm. 17.

[23] T. S. Somantri, Psikologi Anak Luar Biasa. Jakarta: Refika Aditama, 2012

[24] M. Arsanti, "Pemerolehan Bahasa pada Anak (Kajian Psikolinguistik)," vol. 3, no. 2, hlm. 24-47, 2014.

[25] R. Pandudinata, S. Sumarlam, dan K. Saddhono, "Pemerolehan Bahasa Siswa Tunagrahita Kelas VI SD,” $J R$, vol. 11, no. 1, hlm. 48-56, Feb 2018

[26] R. Musdalifah, "Pemrosesan dan Penyimpanan Informasi pada Otak Anak dalam Belajar: Short Term and Long Term Memory," Al-Ishlah: Jurnal Pendidikan Islam, vol. 17, no. 2, hlm. 217-235, 2019.

[27] F. Herlinda, "Meningkatkan Kemampuan Membaca Kata Melalui Media Audio Visual Bagi Anak Slow Learner," EJUPEKhu (Jurnal Ilmiah Pendidikan Khusus), vol. 3, no. 3, hlm. 53-63, 2014.

[28] S. Wulandari dan S. Prasetyaningrum, "Media Stamp Game untuk Meningkatkan Kemampuan Berhitung Anak Slow Learner di Sekolah Dasar,” psy, vol. 5, no. 2, hlm. 131-148, Des 2018. 